\title{
The Importance of Husband Support During Childbirth in Indonesia
}

\section{Pentingnya Dukungan Suami Selama Persalinan di Indonesia}

\author{
Mohammad F. Satrianegara $^{* 1}$, Veni Hadju², Yessy Kurniati ${ }^{3}$ \\ ${ }^{1,3}$ Bagian Kesehatan Masyarakat, Universitas Islam Negeri Alauddin Makassar, Makassar \\ ${ }^{2}$ Bagian Ilmu Gizi, Universitas Hasanuddin, Makassar
}

DOI: 10.24252/al-sihah.v13i1.21398

Received: 14 June 2021 / In Reviewed: 15 June 2021 / Accepted: 27 June 2021 / Available online: 30 June 2021 (C) The Authors 2021. This is an open access article under the CC BY-NC-SA 4.0 license

\begin{abstract}
The Assistance of the husband during the delivery of the wife makes the process smoother. The assistance was related to various factors, including husband support. This study aims to determine the relationship between husband support and wife delivery assistance at the Sheikh Yusuf General Hospital in Gowa Regency. The study was conducted from October-November 2019. This study used a cross-sectional approach the population is all husbands who came to bring their wives in the period of October-November amounted to 385 people. The research sample was obtained by simple random sampling totaling 134 people. Data analysis was performed using SPSS with a chi-square test where the significance value was $p<0.05$. The results showed that the respondents in this study were mostly aged 18-24 years as many as 39.6\%, the last level of education was Senior High School as much as $51.5 \%$ and working as entrepreneurs $38.8 \%$. A small proportion of respondents in this study aged 39-45 years were 4 (3.0\%), D3 education level was 4 (3.0\%), and worked as a repairman 3 (2.2\%). The study also showed that there were $81.3 \%$ of husbands supported childbirth and $18.7 \%$ did not. In addition, there were $64.9 \%$ of husbands accompanied their wives at delivery, and $35.1 \%$ did not accompany them. There is a relationship between the husband's support and delivery assistance $(p=0.008)$. It is expected that the husband can play an active role in assisting his wife so that it helps the smooth delivery process.
\end{abstract}

\begin{abstract}
ABSTRAK
Pendampingan suami saat persalinan istri membuat proses persalinan menjadi lebih lancar. Pendampingan tersebut berhubungan dengan berbagai faktor, di antaranya adalah dukungan suami. Tujuan penelitian ini adalah untuk mengetahui korelasi dukungan suami dengan pendampingan persalinan istri di rumah sakit umum Syekh Yusuf yang terletak Kabupaten Gowa. Penelitian dilaksanakan dengan pendekatan cross-sectional. Populasi penelitian adalah seluruh suami yang datang membawa istrinya bersalin periode Oktober-November, berjumlah 385 orang. Sampel penelitian dipilih secara simple random sampling berjumlah 134 orang. Instrumen penelitian adalah kuesioner yang telah diuji validitas dan reabilitasnya sebelum digunakan. Analisis data dilakukan menggunakan SPSS dengan uji chi-square dimana nilai kemaknaan adalah $\mathrm{p}<0,05$. Penelitian ini memperoleh responden yang sebagian besar berusia 18-24 tahun (39,6\%), tingkat pendidikan terakhir adalah SMA (51,5\%) dan bekerja sebagai wiraswasta (38,8\%). Penelitian ini juga menunjukkan bahwa terdapat $81,3 \%$ suami yang mendukung persalinan istri dan $18,7 \%$ yang tidak mendukung. Selain itu, terdapat $64,9 \%$ suami yang mendampingi istrinya saat persalinan dan 35,1\% yang tidak mendampingi. Hasil uji menunjukkan terdapat hubungan antara dukungan suami dengan pendampingan persalinan $(\mathrm{p}=0,008)$. Hasil penelitian menunjukkan dukungan suami sangat penting dalam kelancaran persalinan istri.
\end{abstract}

\section{GRAPHICAL ABSTRACT}

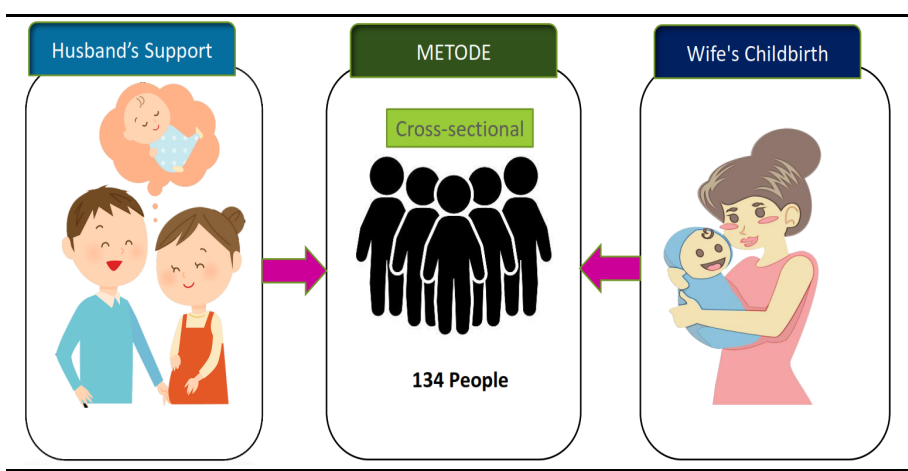

Keyword

assistance; childbirth; husband support; maternal health

Kata Kunci:

dukungan suami; kesehatan ibu; pendampingan; persalinan.

\section{* Correspondence}

BTN CV Dewi Blok B2 no. 16, Makassar, 90231

Email: mfaissatrianegara@gmail.com 


\section{PENDAHULUAN}

Dalam panduan MPS (Making Pregnancy Safer), salah satu cara untuk meningkatkan keterlibatan suami dalam kesehatan reproduksi istri adalah dengan membekalinya informasi (Acharya et al., 2015). Selain itu, perlu melibatkan suami dalam setiap kegiatan peningkatan kesehatan reproduksi (Davis et al., 2016). Dalam proses persalinan, upaya yang dapat dilakukan adalah dengan melibatkan suami dalam pendampingan persalinan istri. Suami juga perlu mendukung upaya rujukan apabila dibutuhkan dalam menyelamatkan istri pada proses persalinan (Salehi et al., 2016; Wilson \& Simpson, 2016).

Suami dapat memberikan pendampingan pada istri selama masa persalinan, contohnya memberi motivasi yang menenangkan hati istri dengan kalimat yang baik, memijat anggota tubuh istri yang nyeri, memberikan minuman atau makanan, menggenggam dan memegang tangan istri saat kontraksi serta meyakinkannya bahwa dia bisa melalui proses persalinan, dan juga membantu memandu istri agar dapat mengedan dengan tepat sesuai petunjuk tenaga kesehatan (Armini et al., 2017; Bertoni \& Brunello, 2017; Tadesse et al., 2018; Wati, 2015).

Beberapa penelitian menemukan hubungan yang signifikan antara umur, pendidikan dan pekerjaan suami dengan pendampingan istri saat melahirkan (Sharifirad et al., 2013; Sihalolo, 2018; Ginting, 2019) Selain itu telah dikaji peran suami pada aspek yang lebih luas yaitu pada kesehatan kehamilan, wilayah pekerjaan rumah tangga, dukungan biaya dan persiapan melahirkan, serta keterlibatan di lingkungan sosial (Phoosuwan, 2020; Eddy \& Fife, 2020; Tehrani et al., 2015; Kaye et al., 2014). Penelitian lain memfokuskan kondisi istri berupa kesejahteraan istri maupun perasaan kepuasan istri yang dihubungkan dengan dukungan keluarga, kesehatan fisik, keamanan serta kenyamanan dengan keluarga selama masa kehamilan hingga persalinan (Chou et al., 2018; DiPietro et al., 2019; Simkhada, et al, 2015) Pada kasus kegawatdaruratan maternal saat persalinan istri, peran suami sebagai pengambil keputusan sangat dibutuhkan (Lewis et al., 2015). Suami adalah penentu dan pengambil keputusan yang menentukan cepat atau lambatnya penanganan kasus kegawatdaruratan pada istri. Pada kondisi tersebut, sangat diharapkan kemampuan suami untuk mengambil keputusan yang efektif serta tepat (Sarwono, 2014).

Beberapa penelitian juga menemukan bahwa peran suami sangat menentukan pada saat kehamilan dan persalinan istri, utamanya pada aspek peran domestik dan peran sosial (Ngoma \& Chongo, 2013; Aktas \& Calik, 2015). Pendapatan keluarga, lama pendidikan suami dan peran suami pada peran domestik dan sosial memiliki pengaruh positif signifikan pada kesejahteraan subjektif istri bersalin (Tang et al., 2019; Sudirman et al., 2019). Namun dari penelitian-penelitian yang telah dilakukan, masih kurang yang mengkaji bagaimana peran dukungan suami terhadap pendampingan persalinan istri.

Penelitian pendahuluan di ruang persalinan Rumah Sakit Umum Daerah (RSUD) Syekh Yusuf melalui interview 
terhadap tenaga kesehatan, menemukan bahwa rata-rata ibu hamil yang akan melakukan persalinan mengalami kecemasan. Beberapa penelitian telah mengungkapkan bahwa faktor kecemasan dapat mempersulit proses persalinan (Jokić-Begić et al., 2014; Dencker et al., 2019; Coşkuner Potur, 2017). Karena itu, istri membutuhkan suami sebagai kerabat terdekat yang diharapkan mampu memberikan rasa tenang dan aman selama proses persalinan. Sayangnya, tidak semua suami memberikan dukungan yang baik terhadap persalinan istri. Demikian pula, tidak semua suami bersedia untuk mendampingi istri saat bersalin. Penelitian ini bertujuan untuk melihat hubungan antara dukungan suami dan pendampingan persalinan istri di RSUD Syekh Yusuf Kabupaten Gowa

\section{METODE PENELITIAN}

Penelitian ini dilakukan di RSUD Syekh Yusuf Kabupaten Gowa sejak bulan Oktober sampai November tahun 2019. Penelitian ini dilakukan dengan desain kuantitatif menggunakan metode cross-sectional study. Penelitian ini berupaya mengetahui hubungan antara dukungan suami dan pendampingan persalinan istri, di mana data semua variabel diambil secara bersamaan. Populasi penelitian adalah seluruh suami yang datang untuk membawa istrinya bersalin periode Oktober-November 2019 berjumlah 385 orang. Para suami ini tidak semuanya mendampingi istrinya saat melahirkan. Karena mereka sekedar mengantar lalu pulang ataupun tidak masuk mendampingi saat proses persalinan.
Sampel penelitian diperoleh secara simple random sampling dengan jumlah sebanyak 134 orang.

Penggunaan instrumen pada penelitian ini yaitu dengan lembar kuesioner yang berisi daftar pertanyaan tentang identitas responden, seperti nama, umur, pendidikan, pekerjaan dan alamat. Kuesioner juga memuat pertanyaan tentang pendampingan persalinan istri serta dukungan suami. Pertanyaan tentang dukungan suami terdiri dari 16 butir pertanyaan, yang memuat substansi seperti dukungan pada istri ketika mengikuti pesan petugas kesehatan, kesediaan untuk mendengarkan keluhan istri, membantu istri menghadapi kecemasaan karena persalinan, penghargaan terhadap pengorbanan istri saat bersalin, kesiagaan sebagai suami serta kesediaan untuk membantu istri dalam menyelesaikan pekerjaan rumah tangga. Kuesioner ini telah diuji validitas dan reabilitasnya sebelum digunakan. Kuesioner diujicobakan pada subjek yang sejenis dengan populasi penelitian, yaitu suami yang mengantarkan istrinya bersalin. Hasil dari uji coba kuesioner kemudian dianalisis untuk mengetahui validitas dan reliabilitasnya. Pertanyaan-pertanyaan yang sulit serta tidak sesuai lalu diperbaiki, sebelum kuesioner digunakan.

Pendampingan persalinan istri pada penelitian ini yaitu suami selama proses persalinan mendampingi istri di ruang bersalin. Mendampingi apabila responden berada di dalam ruang bersalin bersama istri dan tidak mendampingi jika responden berada di luar ruang bersalin saat 
Tabel 1

Karakteristik Responden

\begin{tabular}{lcc}
\hline Karakteristik Suami & Frekuensi & Persentasi (\%) \\
\hline Usia (tahun) & & \\
$18-24$ & 53 & 39.6 \\
$25-31$ & 52 & 38.8 \\
$32-38$ & 25 & 18.7 \\
$39-45$ & 4 & 3 \\
Pendidikan & & \\
Tidak Sekolah & 4 & 3 \\
SD & 17 & 12.7 \\
SMP & 15 & 11.2 \\
SMA & 69 & 51.5 \\
D3 & 4 & 3 \\
S1 & 25 & 18.7 \\
Pekerjaan & & \\
Buruh & 21 & 15.8 \\
Pedagang & 5 & 3.7 \\
Petani & 20 & 14.9 \\
PNS & 28 & 20.9 \\
Supir & 5 & 3.7 \\
Tukang Bengkel & 3 & 2.2 \\
Wiraswasta & 52 & 38.8 \\
\hline
\end{tabular}

istrinya melahirkan. Dukungan suami yang dimaksud dalam penelitian ini adalah dukungan yang diberikan oleh suami kepada istri dalam bentuk dukungan emosional dan dukungan informasional. Data diolah dengan menggunakan uji chisquare dengan nilai kemaknaan $\mathrm{p}<0,05$. Penelitian ini telah mendapatkan persetujuan etik dari Komisi Etik Penelitian Kesehatan Fakultas Kedokteran dan Ilmu Kesehatan Universitas Islam Negeri Alauddin Makassar dengan nomor A 231/KEPK/ FKIK/X/2019

\section{HASIL PENELITIAN}

Berdasarkan tabel 1, terlihat bahwa usia responden terbanyak pada kelompok 18-24 tahun sebanyak 53 $(39,6 \%)$ dan terendah pada usia 39-45 tahun sebanyak $4(3,0 \%)$, tingkat pendidikan responden yang terbanyak adalah Sekolah Menengah Atas sebanyak 69 (51,5\%) dan yang terendah D3 sebanyak 4 (3,0\%). Pekerjaan responden yang terbanyak adalah wiraswasta sebanyak 52 (38,8\%) sedangkan yang paling sedikit adalah tukang bengkel 3 $(2,2 \%)$

Berdasarkan gambar 1, terlihat bahwa sebagian besar responden mendukung persalinan istri yaitu $81,3 \%$. Pada gambar tersebut juga menunjukkan bahwa yang mendampingi persalinan istri tidak sebanyak yang mendukung, yaitu sebesar 64,9\%. Berdasarkan tabel 2, terlihat bahwa suami yang mendukung istrinya dan mendampingi persalinan terdapat 70 . 6\%, sedangkan yang tidak mendukung namun mendampingi persalinan terdapat $29.3 \%$. Suami yang tidak mendukung namun mendampingi istrinya terdapat $40.0 \%$ dari re- 
Tabel 2

Hubungan antara Dukungan dan Pendampingan Suami pada Persalinan Istri

\begin{tabular}{|c|c|c|c|c|c|}
\hline \multirow[t]{3}{*}{ Dukungan Suami } & \multicolumn{4}{|c|}{ Pendampingan Persalinan } & \multirow[t]{3}{*}{ P-value } \\
\hline & \multicolumn{2}{|c|}{ Mendampingi } & \multicolumn{2}{|c|}{ Tidak mendampingi } & \\
\hline & $\mathrm{n}$ & $\%$ & $\mathrm{n}$ & $\%$ & \\
\hline Mendukung & 77 & 70.6 & 32 & 29.4 & \multirow{2}{*}{$0.008 *$} \\
\hline Tidak Mendukung & 10 & 40 & 15 & 60 & \\
\hline
\end{tabular}

sponden. Sedangkan suami yang tidak mendukung dan tidak mendampingi persalinan istri terdapat $60.0 \%$. Berdasarkan uji chi-square yang dilakukan terhadap variabel independen, yaitu dukungan suami dan variabel dependen, yaitu pendampingan persalinan istri, ditemukan nilai $\mathrm{p}$ yang signifikan, yaitu $p=0,008$. Sehingga penelitian ini menemukan adanya hubungan yang signifikan antara dukungan suami dan pendampingan persalinan istri

\section{PEMBAHASAN}

Dukungan adalah tersedianya sumber daya yang menciptakan kenyamanan fisik dan psikologis. Dukungan dapat diberikan dalam bentuk pengetahuan bahwa individu tersebut dicintai, dihargai dan diperhatikan oleh orang lain. Selain itu, individu tersebut juga merasa bahwa ia adalah anggota sebuah kelompok yang berdasarkan kepentingan bersama. Dukungan suami adalah pemberian bantuan yang sangat bermanfaat secara emosional serta memberikan pengaruh positif kepada istri, dalam bentuk pemberian informasi, bantuan instrumental, emosi, maupun penilaian. Dukungan ini sangat dibutuhkan oleh istri, baik saat hamil maupun saat persalinan. Dukungan yang diberikan oleh suami akan sangat ber- manfaat bagi istri, ketika menghadapi berbagai kondisi sulit dalam kehamilan dan persalinan.

Sebagaimana diketahui, bahwa persalinan adalah proses yang membutuhkan perjuangan dari seorang istri. Saat bersalin merupakan perjuangan antara hidup dan mati bagi seorang perempuan. Persalinan menimbulkan rasa sakit dan risiko kesehatan serta kematian bagi seorang istri. Penyebab kematian ibu di antaranya adalah karena persalinan yang berisiko. Sehingga, seorang istri sangat membutuhkan dukungan dari berbagai pihak ketika dia tengah menghadapi persalinan. Utamanya adalah dukungan dari suami. Adanya dukungan dari suami akan memudahkan proses persalinan bagi sang istri.

Penelitian ini menemukan hubungan antara dukungan suami dengan pendampingan persalinan. Hasil penelitian ini menunjukkan bahwa dukungan suami merupakan reinforcing faktor (faktor penguat) yang membuat seseorang pada obyek tertentu dapat bertindak. Namun faktor penguat ini dapat bersifat negatif atau positif tergantung perilaku dan sikap. Dukungan suami dapat mempengaruhi persalinan istri secara positif. Dimana, pendampingan yang dilakukan oleh suami dapat memberikan kenyamanan dan 


\section{Gambar 1}

Grafik Persentase Dukungan dan Pendampingan Persalinan Istri

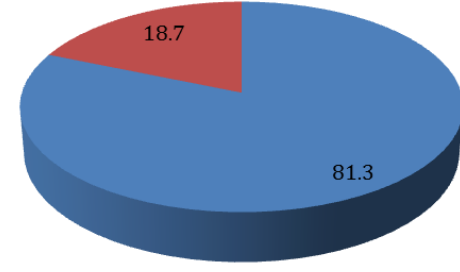

- Mendukung - Tidak mendukung

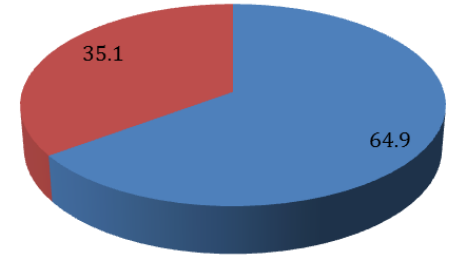

- Mendamping

- Tidak Mendampingi menurunkan tingkat stres istri yang menghadapi proses bersalin.

Pendampingan suami dalam persalinan memberikan berbagai manfaat. Seperti menurunnya tingkat kecemasan, penurunan intensitas nyeri serta kemajuan persalinan. Penelitian yang dilakukan untuk melihat peranan dukungan suami, menemukan bahwa ada pengaruh yang signifikan dari pendampingan suami dengan penurunan nyeri saat proses persalinan (Boryri et al., 2016). Studi lain yang telah dilakukan menemukan ada hubungan yang kuat antara dukungan suami dengan timbulnya kecemasan istri hamil menjelang persalinan (Weis et al., 2017). Selain itu hasil penelitian lain menemukan dukungan pasangan, teman, rekan kerja dan akan menunjang kesehatan mental ibu, khususnya pada periode pascakelahiran serta dapat mengatasi gejala depresi, kecemasan, dan efikasi diri (Razurel \& Kaiser, 2015). Pendampingan suami juga dapat membantu kemajuan persalinan kala 1 fase aktif (Sari et al., 2020). Meski ada pula studi yang menunjukkan sebaliknya. Bahwa tidak ada pengaruh yang bermakna antara pendampingan suami dengan lama persalinan (Wati \& Putri, 2018).

Pendampingan oleh suami sangat mendukung kesuksesan persalinan. Peran suami dalam kesehatan ibu saat persalinan sangat penting. Suami memiliki peran yang krusial dalam mendampingi istrinya saat bersalin. Suami tidak hanya membantu memenuhi kebutuhan istri saat persalinan, tetapi juga membantu istri merasa lebih nyaman. (Lestari \& Mufdlilah, 2019). Dukungan suami dapat menjadi penghalang akibat negatif dari faktor stres menjelang persalinan. Selain itu, dukungan suami dapat mencegah ibu mengalami penurunan kualitas hidup setelah persalinan (Gebuza et al., 2016). Dukungan suami merupakan faktor yang meningkatkan rasa puas ibu saat persalinan (Catala et al., 2020).

Studi yang dilakukan terhadap 126 ibu hamil pada trimester 3 di Kota Bekasi menemukan bahwa terhadap $45,2 \%$ ibu hamil yang mengalami ketakutan menjelang persalinan. Rasa takut menghadapi persalinan diprediksi oleh faktor dukungan suami dan kecemasan ibu. Dukungan suami yang rendah meningkatkan rasa takut pada ibu saat persalinan sehingga dibutuhkan upaya untuk meningkatkan dukungan suami pada proses persalinan (Marcelina et al., 2019). Karena itu penting untuk memberikan pembekalan kepada pasangan usia subur tentang kehamilan dan persalinan. 
Pembekalan tersebut diharapkan dapat meningkatkan dukungan suami sehingga membantu terselenggaranya proses persalinan tanpa menimbulkan ketakutan istri (Arfaie et al., 2017).

Suami diharapkan untuk mendampingi istri saat bersalin, karena hal tersebut dapat mengurangi kecemasan istri. Hasil penelitian ini menunjukkan bahwa suami yang mendampingi persalinan ternyata dapat menyalurkan dukungan yang tepat kepada istri, hal ini dibuktikan dengan hasil yang didapatkan yaitu terdapat $70.6 \%$ yang mendukung dan mendampingi persalinan. Hal ini lebih tinggi dari jumlah responden yang mendukung tetapi tidak mendampingi yaitu sebanyak $29.4 \%$.

Kehadiran suami sebagai pendamping persalinan memiliki pengaruh terhadap proses persalinan, khususnya dalam mempercepat lama kala II. Hadirnya suami dapat mengurangi rasa cemas pada ibu saat bersalin. Selain itu, kestabilan emosi ibu akan lebih terjaga, ibu akan merasa lebih tenang, nyaman dan rileks serta bertambah semangat dan kepercayaan dirinya saat bersalin . Sehingga ibu akan lebih mudah untuk mengedan dan akhirnya mempercepat proses persalinan kala II (Mutiara et al., 2021).

Suami diharapkan berperan aktif mendukung istri dan mengidentifikasi langkah-langkah yang perlu dilakukan demi kenyamanan istri. Keinginan ibu bersalin untuk menghadirkan teman atau saudara untuk menemaninya perlu untuk dihargai. Dukungan suami akan mempengaruhi sistem limbik istri yaitu dalam hal emosi. Istri yang tenang emosinya, akan menyebabkan melimpahnya produksi hormon oksitosin. Hormon tersebut akan meningkatkan kontraktilitas uterus pada akhir kehamilan untuk mengeluarkan bayi (Guyton \& Hall, 2016).

Sebuah studi menemukan bahwa kehadiran pendamping saat persalinan dapat mendorong istri untuk tidak merasa cemas, merasakan ketenangan, kenyamanan, dan semangat. Simpati dan rasa sayang yang diberikan kepada istri dari suami pada saat proses melahirkan akan memberikan kekuatan tersendiri yang akan menimbulkan semangat istri melalui proses persalinan dengan lebih kuat. Jadi dalam mendukung proses persalinan sehingga dapat berlangsung baik, maka pendampingan suami sangat berperan aktif (Khusnul, 2018). Ibu yang mendapat dukungan dari suami menunjukkan persalinan yang lebih singkat, mengurangi kebutuhan terhadap oksitosin, analgesic, anastesi, alat bantu persalinan serta memiliki kemungkinan 50\% lebih rendah untuk melahirkan secara sesar (Bohren et al., 2017).

Pengetahuan yang rendah tentang kesehatan ibu menjadi tantangan yang signifikan bagi terlibatnya suami dalam pendampingan persalinan (Nesane et al., 2016). Faktor lain yang mempengaruhi niat suami untuk terlibat dalam pendampingan persalinan adalah tingkat pendidikan. Beberapa studi menunjukkan bahwa suami yang memiliki tingkat pendidikan lebih tinggi memberikan dukungan yang lebih baik dalam persalinan istri 
(Vehviläinen-Julkunen \& Emelonye, 2014). Faktor lain seperti ketidapedulian, kemiskinan, adat dan pratek religisuitas juga menjadi penyebab rendahnya partisipasi pasangan dalam pendampingan persalinan (Lowe, 2017).

Sebuah studi kualitatif yang dilakukan di Tanzania menemukan bahwa suami yang mendukung pasangannya selama hamil dan melahirkan, merefleksikan diri mereka sebagai laki-laki modern. Lakilaki tersebut bersedia membantu pekerjaan rumah tangga di samping tugas yang biasa mereka laksanakan. Hal tersebut mereka lakukan untuk memberikan kesempatan kepada istrinya untuk beristirahat (Kashaija et al., 2020). Variabel signifikan yang mempengaruhi kesertaan suami adalah usia dan pendidikan istri, pendidikan suami, status pekerjaan istri dan suami, pendidikan suami, status pekerjaan istri dan suami, jumlah anak, status persalinan dan tempat tinggal (Rumaseuw et al., 2018).

Studi kualitatif yang dilakukan di Ethiopia Selatan menemukan bahwa faktor -faktor yang menghalangi suami untuk memberikan dukungan kepada istri saat hamil dan melahirkan adalah karena mereka menganggap bahwa hamil dan melahirkan merupakan daur hidup alami bagi setiap perempuan. Selain itu, para suami tersebut berpendapat bahwa hamil dan melahirkan merupakan urusan perempuan (Teklesilasie \& Deressa, 2020). Padahal, sebagai pasangan orang tua, suami dan istri memiliki kewajiban yang sama dalam proses kehamilan dan persalinan. Para suami berkewajiban untuk melindungi dan memberikan segala dukungan yang dibutuhkan oleh istrinya.

Studi di Cina, menemukan bahwa kebutuhan ibu pada bulan pertama pasca salin adalah kebutuhan untuk meningkatkan energi, kebutuhan untuk meningkatkan rasa keibuan, kebutuhan terhadap dukungan keluarga serta teman juga kebutuhan untuk dimengerti (Yeh et al., 2017). Pasca salin ini ibu bisa mengalami depresi. Depresi ini biasanya disebut sebagai depresi postpartum. Yaitu gangguan kejiwaan yang dialami ibu setelah persalinan sampai satu tahun kemudian. Penyebabnya terdiri dari faktor biologi dan psikososial. Faktor biologi yang berpengaruh misalnya defisiensi zat gizi tertentu (Kurniati, 2017). Namun penelitian yang dilakukan Kurniati, menemukan bahwa faktor yang berhubungan dengan kejadian depresi postpartum pada ibu adalah dukungan suami (Kurniati \& Sinrang, 2020).

Kehamilan dan persalinan dapat menjadi pengalaman yang traumatis bagi ibu. Pengalaman negatif saat persalinan akan terus membekas pada ibu sepanjang sisa hidupnya (McKenzie-McHarg et al., 2015; De Schepper et al., 2016) Selain itu, kehamilan dan persalinan merupakan proses yang berisiko tinggi terhadap kesehatan ibu. Bahkan dapat mengancam jiwa ibu dan anaknya. Sehingga segala upaya yang diperlukan untuk menyelamatkan ibu, termasuk meningkatkan dukungan dan pendampingan suami saat persalinan, perlu diusahakan.

Suami dan istri adalah mitra dalam rumah tangga. Ketika istri menghadapi proses berbahaya sebagai konsekuensi dari peran kodrati, maka seharusnya suami 
hadir untuk memberikan dukungan. Tidak hanya dukungan ketika istri mengalami kehamilan. Namun juga dukungan saat istri tengah melahirkan. Dukungan tersebut akan semakin lengkap, ketika suami juga berperan dalam proses perawatan dan pengasuhan bayi. Karena anak bukan hanya merupakan tanggung jawab ibunya. Suami dan istri memiliki peran yang sama dan penting dalam menunjang tumbuh kembang anak-anak mereka. Rumah tangga yang ditopang dengan kerja sama yang baik antara suami dan istri, akan menjadi rumah tangga yang sehat, baik sehat jasmani, rohani, sosial dan ekonomi.

Penelitian ini memberikan kontribusi terhadap bukti pentingnya dukungan suami terhadap persalinan istri dan hubungan antara keduanya Studi ini mendukung pentingnya pelibatan suami dalam menunjang kesehatan ibu dan anak. Sehingga tenaga kesehatan diharapkan dapat memberi ruang bagi terlibatnya suami dalam pendampingan persalinan.

\section{KESIMPULAN}

Penelitian ini menemukan hubungan yang signifikan antara dukungan suami dan pendampingan persalinan istri. Sebagian besar responden mendukung persalinan dan melakukan pendampingan terhadap persalinan istrinya. Meski masih terdapat pula yang tidak mendukung dan tidak mendampingi istrinya saat bersalin. Penelitian ini memiliki keterbatasan karena tidak melakukan ekplorasi secara mendalam tentang faktor-faktor yang berhubungan dengan pendampingan persalinan oleh suami. Sehingga belum memberikan pemahaman yang menyeluruh tentang pendampingan suami terhadap persalinan istri.

Para suami perlu memberikan dukungan dan pendampingan saat persalinan istri. Dukungan suami akan memberikan kenyamanan emosional bagi istri. Selain itu, dengan pendampingan saat persalinan istri, para suami dapat menyaksikan secara langsung perjuangan istri ketika melahirkan serta membantu mengambil keputusan secara cepat ketika terjadi kedaruratan saat persalinan. Selain itu, perlu dilakukan kajian secara kualitatif untuk mendalami faktor-faktor penyebab suami mendukung dan mendampingi persalinan istrinya serta faktor-faktor penyebab suami tidak mendukung dan mendampingi persalinan istri. Sehingga diharapkan dengan data tersebut dapat dikembangkan program kesehatan ibu dan anak yang dapat meningkatkan dukungan dan pendampingan suami saat persalinan.

\section{UCAPAN TERIMA KASIH}

Penulis mengucapkan terima kasih kepada seluruh responden yang terlibat pada penelitian ini serta pihak Rumah Sakit Umum Syekh Yusuf Kabupaten Gowa yang telah memfasilitasi sehingga penelitian ini dapat terlaksana dengan baik. Penulis juga mengucapkan terima kasih kepada Dr. St. Raodhah, M.Kes yang membantu memperbaiki metodelogi artikel ini dan kepada Syamsul Alam, SKM. yang membantu mengumpulkan dan mengolah data primer. 


\section{DAFTAR PUSTAKA}

Acharya, A. S., Kaur, R., Prasuna, J. G., \& Rasheed, N. (2015). Making pregnancy safer-birth preparedness and complication readiness study among antenatal women attendees of a primary health center, Delhi. Indian journal of community medicine: official publication of Indian Association of Preventive \& Social Medicine, 40(2), 127. https:// dx.doi.org/10.4103\%2F09700218.153881

Aktas, S., \& Calik, K. Y. (2015). Factors affecting depression during pregnancy and the correlation between social support and pregnancy depression. Iranian Red Crescent Medical Journal, 17(9). https:// dx.doi.org/10.5812\%2Fircmj. 16640

Arfaie, K., Nahidi, F., Simbar, M., \& Bakhtiari, M. (2017). The role of fear of childbirth in pregnancy related anxiety in Iranian women: a qualitative research. Electronic physician, $9(2), \quad 3733$. https://dx.doi.org/10.19082\%2F3733

Armini, N. K. A., Tristiana, R. D., \& Tokan, A. O. (2017, April). Husband's Support is Needed to Prevent Postpartum Depression. In 8th International Nursing Conference on Education, Practice and Research Development in Nursing (INC 2017). Atlantis Press. https://dx.doi.org/10.2991/inc17.2017 .7

Bertoni, M., \& Brunello, G. (2017). Pappa Ante Portas: The effect of the husband's retirement on the wife's mental health in Japan. Social Science \& Medicine, 175, 135-142. https://doi.org/10.1016/j.socscimed.2 017.01 .012

Bohren, M. A., Hofmeyr, G. J., Sakala, C.,
Fukuzawa, R. K., \& Cuthbert, A. (2017). Continuous support for women during childbirth. Cochrane Database of Systematic Reviews, (7). https://doi.org/10.1002/14651858.C D003766.pub6

Boryri, T., Noori, N. M., Teimouri, A., \& Yaghobinia, F. (2016). The perception of primiparous mothers of comfortable resources in labor pain (a qualitative study). Iranian journal of nursing and midwifery research, 21(3), 239. https://dx.doi.org/10.4103\%2F17359066.180386

Catala, P., Peñacoba, C., Carmona, J., \& Marin, D. (2020). Do maternal personality variables influence childbirth satisfaction? A longitudinal study in low-risk pregnancies. Women \& health, 60(2), 197211.

https://doi.org/10.1080/03630242.20 19.1613473

Chou, J. L., Pierce, K. J., Pennington, L. B., Seiler, R., Michael, J., Mc Namara, D., \& Zand, D. (2018). Social support, family empowerment, substance use, and perceived parenting competency during pregnancy for women with substance use disorders. Substance use \& misuse, 53(13), 2250-2256. https://doi.org/10.1080/10826084.20 18.1467456

Coşkuner Potur, D., Mamuk, R., Şahin, N. H., Demirci, N., \& Hamlaci, Y. (2017). Association between fear of childbirth and maternal acceptance of pregnancy. International nursing review, 64(4), 576-583. https://doi.org/10.1111/inr.12378

Davis, J., Vyankandondera, J., Luchters, S., Simon, D., \& Holmes, W. (2016). Male involvement in reproductive, 
maternal and child health: a qualitative study of policymaker and practitioner perspectives in the Pacific. Reproductive health, 13(1), 1-11. https://doi.org/10.1186/s12978-0160184-2

De Schepper, S., Vercauteren, T., Tersago, J., Jacquemyn, Y., Raes, F., \& Franck, E. (2016). Post-Traumatic Stress Disorder after childbirth and the influence of maternity team care during labour and birth: A cohort study. Midwifery, 32, 87-92. https://doi.org/10.1016/j.midw.2015 .08 .010

Dencker, A., Nilsson, C., Begley, C., Jangsten, E., Mollberg, M., Patel, H., \& Sparud-Lundin, C. (2019). Causes and outcomes in studies of fear of childbirth: a systematic review. Women and Birth, 32(2), 99111.

https://doi.org/10.1016/j.wombi.201 8.07.004

DiPietro, L., Evenson, K. R., Bloodgood, B., Sprow, K., Troiano, R. P., Piercy, K. L., ... \& Powell, K. E. (2019). Benefits of physical activity during pregnancy and postpartum: an umbrella review. Medicine and science in sports and exercise, 51(6), 1292. https://dx.doi.org/10.1249\%2FMSS. 0000000000001941

Eddy, B. P., \& Fife, S. T. (2020). Active husband involvement during pregnancy: A grounded theory. Family Relations. https://doi.org/10.1111/fare.12486

Gebuza, G., Kaźmierczak, M., Mieczkowska, E., Gierszewska, M., \& Banaszkiewicz, M. (2016). Adequacy of social support and satisfaction with life during childbirth. Polish Annals of Medicine, 23(2), 135-140. https://doi.org/10.1016/j.poamed.20 16.01.004

Ginting, L. (2019). Hubungan Pengetahuan dan Sikap Pendampingan Suami terhadap Istri dalam Persalinan. Jurnal Ilmiah Keperawatan Imelda, 5(1), 612-616. https://dx.doi.org/10.2411/jikeperaw atan.v5i1.311

Guyton, A. C., \& Hall, J. E. (2016). Buku Ajar Fisiologi Kedokteran Edisi XII. Jakarta: Penerbit Buku Kedokteran EGC.

Jokić-Begić, N., Žigić, L., \& Nakić Radoš, S. (2014). Anxiety and anxiety sensitivity as predictors of fear of childbirth: different patterns for nulliparous and parous women. Journal of Psychosomatic Obstetrics \& Gynecology, 35(1), 22-28. https://doi.org/10.3109/0167482x.20 13.866647

Kashaija, D., Mselle, L. \& Mkoka, D. (2020). Husbands' experience and perception of supporting their wives during childbirth in Tanzania. BMC Pregnancy Childbirt, 20(85) https://doi.org/10.1186/s12884-0192715-7

Kaye, D. K., Kakaire, O., Nakimuli, A., Osinde, M. O., Mbalinda, S. N., \& Kakande, N. (2014). Male involvement during pregnancy and childbirth: men's perceptions, practices and experiences during the care for women who developed childbirth complications in Mulago Hospital, Uganda. BMC pregnancy and childbirth, 14(1), 1-8. https://doi.org/10.1186/1471-239314-54

Kurniati, Y. (2017). Kajian Pustaka: Peran Zink Pada Depresi Postpartum. Media Gizi Mikro Indone- 
sia, $\quad 9(1), \quad 61-72$. https://doi.org/10.22435/mgmi.v9i1. 1009

Kurniati, Y., \& Sinrang, W. (2020). Postpartum blues syndrome: Serum zinc and psychosocial factors. Enfermeria clinica, 30, 18-21. https://doi.org/10.1016/j.enfcli.2019. 07.019

Lestari, P., \& Mufdlilah, D. E. (2019, November). Husband's Role In Assistance Of Laboring Process: Systematic Literature Review. In Proceeding International Conference (Vol. 1, No. 1, pp. 142-151). http://prosiding.respati.ac.id/index.p $\mathrm{hp} / \mathrm{PIC} /$ article/view/69

Lewis, S., Lee, A., \& Simkhada, P. (2015). The role of husbands in maternal health and safe childbirth in rural Nepal: a qualitative study. $B M C$ pregnancy and childbirth, 15(1), 110. https://doi.org/10.1186/s12884015-0599-8

Lowe, M. (2017). Social and cultural barriers to husbands' involvement in maternal health in rural Gambia. The Pan African medical journal, 27. https://dx.doi.org/10.11604\%2Fpamj .2017 .27 .255 .11378

Marcelina, L. A., Rachmawati, I. N., \& Ungsianik, T. (2019). Dissatisfaction with the husband support increases childbirth fear among Indonesian primigravida. Enfermeria clinica, 29, 379-383.

https://doi.org/10.1016/j.enfcli.2019. 04.047

McKenzie-McHarg, K., Ayers, S., Ford, E., Horsch, A., Jomeen, J., Sawyer, A., \& Slade, P. (2015). Post-traumatic stress disorder following childbirth: an update of current issues and recommendations for future re- search. Journal of Reproductive and Infant Psychology, 33(3), 219-237. https://doi.org/10.1080/02646838.20 15.1031646

Mutiara, V. S., Wulandari, E., Rahmawati, I., \& Yusanty, N. (2021). Hubungan pendamping suami dengan kala dua lama pada ibu bersalin. Prepotif: Jurnal Kesehatan Masyarakat, 5(1), 118-124.

https://doi.org/10.31004/prepotif.v5i 1.1375

Nesane, K., Maputle, S., \& Shilubane, H. (2016). Male partners' views of involvement in maternal healthcare services at Makhado Municipality clinics, Limpopo Province, South Africa. African Journal of Primary Health Care \& Family Medicine, $8(2)$.

https://doi.org/10.4102/phcfm.v8i2.9 29

Ngoma, C. M., \& Chongo, C. (2013). Support during pregnancy, labour and childbirth by husbands in Zambia. African Journal of Midwifery and Women's Health, 7(4), 186-190. https://doi.org/10.12968/ajmw.2013. 7.4.186

Nikmah, K. (2018). Hubungan Pendampingan Suami dengan Tingkat Kecemasan Ibu Primi Gravidarum saat Menghadapi Persalinan. Journal for Quality in Women's Health, 1(2), 15-21.

https://www.jqwh.org/index.php/JQ

$\mathrm{WH} /$ article/view/12

Phoosuwan, N., Manasatchakun, P., Eriksson, L., \& Lundberg, P. C. (2020). Life situation and support during pregnancy among Thai expectant mothers with depressive symptoms and their partners: a qualitative study. BMC pregnancy and childbirth, 20, 1-10. 
https://doi.org/10.1186/s12884-02002914-y

Razurel, C., \& Kaiser, B. (2015). The role of satisfaction with social support on the psychological health of primiparous mothers in the perinatal period. Women \& health, 55(2), 167186.

https://doi.org/10.1080/03630242.20 14.979969

Rumaseuw, R., Berliana, S. M., Nursalam, N., Efendi, F., Pradanie, R., Rachmawati, P. D., \& Aurizki, G. E. (2018, February). Factors affecting husband participation in antenatal care attendance and delivery. In $I O P$ Conference Series: Earth and Environmental Science (Vol. 116, No. 1, p. 012012). IOP Publishing. https://iopscience.iop.org/article/10.1 088/1755-1315/116/1/012012

Salehi, A., Fahami, F., \& Beigi, M. (2016). The effect of presence of trained husbands beside their wives during childbirth on women's anxiety. Iranian journal of nursing and midwifery research, 21(6), 611. https://dx.doi.org/10.4103\%2F17359066.197672

Sari, D. E. A., Sari, N. I., \& Zulaikha, N. P. (2020). Hubungan pendampingan suami dalam persalinan dengan kemajuan persalinan kala I fase aktif di RB. Bunda Puja Tembilahan. Selodang Mayang: Jurnal Ilmiah Badan Perencanaan Pembangunan Daerah Kabupaten Indragiri Hilir, 6(1), 31-38. https://doi.org/10.47521/selodangma yang.v6i1.144

Sharifirad, G., Rezaeian, M., Soltani, R., Javaheri, S., \& Mazaheri, M. A. (2013). A survey on the effects of husbands' education of pregnant women on knowledge, attitude, and reducing elective cesarean section. Journal of education and health promotion, 2. https://dx.doi.org/10.4103\%2F22779531.119036

Tadesse, M., Boltena, A. T., \& Asamoah, B. O. (2018). Husbands' participation in birth preparedness and complication readiness and associated factors in Wolaita Sodo town, Southern Ethiopia. African journal of primary health care \& family medicine, $\quad 10(1), \quad 1-8$. http://dx.doi.org/10.4102/phcfm.v10i 1.1471

Tang, X., Lu, Z., Hu, D., \& Zhong, X. (2019). Influencing factors for prenatal stress, anxiety and depression in early pregnancy among women in Chongqing, China. Journal of affective disorders, 253, 292-302. https://doi.org/10.1016/j.jad.2019.05. 003

Tehrani, S. G., Bazzazian, S., \& Nayeri, N. D. (2015). Pregnancy experiences of first-time fathers in Iran: a qualitative interview study. Iranian Red Crescent Medical Journal, 17(2). https://dx.doi.org/10.5812\%2Fircmj. 12271

Teklesilasie, W., \& Deressa, W. (2020). Barriers to husbands' involvement in maternal health care in Sidama zone, Southern Ethiopia: a qualitative study. BMC pregnancy and childbirth, 20(1), 1-8. https://doi.org/10.1186/s12884-0192697-5

Vehviläinen-Julkunen, K., \& Emelonye, A. (2014). Spousal participation in labor and delivery in nigeriaa. Annals of medical and health sciences research, 4(4), 511-515. https://doi.org/10.4103/21419248.139290 
Wati, L., \& Putri, A. E. (2018). Pengaruh Pendampingan Suami Dan Paritas Terhadap Lama Persalinan Kala II Pada Ibu Bersalin Di Bidan Praktek Mandiri Pariaman. Health Science Growth (HSG) Journal, 3(2). https://journal.unsika.ac.id/index.php /HSG/article/view/1683

Weis, K. L., Lederman, R. P., Walker, K. C., \& Chan, W. (2017). Mentors offering maternal support reduces prenatal, pregnancy-specific anxiety in a sample of military women. Journal of Obstetric, Gynecologic \& Neonatal Nursing, 46(5), 669-685. https://doi.org/10.1016/j.jogn.2017.0
7.003

Wilson, C. L., \& Simpson, J. A. (2016). Childbirth pain, attachment orientations, and romantic partner support during labor and delivery. Personal Relationships, 23(4), 622-644. https://doi.org/10.1111/pere.12157

Yeh, Y. C., St John, W., Chuang, Y. H., \& Huang, Y. P. (2017). The care needs of postpartum women taking their first time of doing the month: a qualitative study. Contemporary nurse, 53(5), 576-588. https://doi.org/10.1080/10376178.20 17.1389615 